\title{
EVALUATION OF THE ANTIBACTERIAL POTENTIAL OF DESERT TRUFFLES (Terfezia spp) EXTRACTS AGAINST METHICILLIN RESISTANT Staphylococcus aureus (MRSA)
}

\author{
Hanaa M. Malik ${ }^{1}$, Munazza Gull ${ }^{1}$, Ulfat $\operatorname{Omar}^{1}$,Taha Abdullah Kumosani ${ }^{1}$, \\ Ahmed Mahmoud Al-Hejin², Hani Z Marzouki ${ }^{3}$, Archana P. lyer ${ }^{1}$
}

${ }^{1}$ Department of Biochemistry, Faculty of Science, King Abdulaziz University, Jeddah, Saudi Arabia

${ }^{2}$ Department of Biological Science, Faculty of Science, King Abdulaziz University, Jeddah, Saudi Arabia

${ }^{3}$ Department of Otolaryngology, Faculty of Medicine, King Abdulaziz University, Jeddah, Saudi Arabia

Received - May 23, 2018; Revision - July 29, 2018; Accepted - August 05, 2018

Available Online - August 10, 2018

DOI: http://dx.doi.org/10.18006/2018.6(4).652.660

KEYWORDS

Desert truffles

Crude extracts

MRSA

Terfezia claveryi

Terfezia nivea

* Corresponding author

E-mail: munagull@hotmail.com (Dr. Munazza Gull)

Peer review under responsibility of Journal of Experimental Biology and Agricultural Sciences.

Production and Hosting by Horizon Publisher India [HPI] (http://www.horizonpublisherindia.in/).

All rights reserved.

\begin{abstract}
Desert truffles are well known for its medicinal and functional food values. These mushrooms are widely used for its antibacterial properties and as a source of protein in Saudi Arabia and many other countries around the world. Methicillin Resistant Staphylococcus aureus (MRSA) has been known for its virulence and multidrug resistant that became threat for hospital employees and community members. Present study was designed to test the common occurrence of MRSA isolates in hospital employees and patients by nasal swab samplings and then evaluate the antibacterial potential of desert truffles against these MRSA. PCR assays revealed that 17 (34\%) bacterial isolates of nasal carriage found MRSA positive while in case of gender no significant association was reported in MRSA positive males and females. Further it was also reported that highest rate of MRSA positive isolates was found for the age group of 20-29 years, among the youngest participants. For testing antibacterial potential of Desert truffles, two wells of $6 \mathrm{~mm}$ diameter were punched on Muller-Hinton Agar that already had MRSA culture, one of them filled cautiously with $100 \mu$ l of Terfezia claveryi extract and the other one with $100 \mu \mathrm{l}$ of Terfezia nivea, stored at $4^{\circ} \mathrm{C}$ for 2 hours. After incubation at $37^{\circ} \mathrm{C}$ for $24 \mathrm{~h}$, the fresh crude extracts of $T$. claveryi showed a significant zone of inhibition $(27 \pm 7.75 \mathrm{~mm})$ while this inhibition was reported $(22.5 \pm 11.26 \mathrm{~mm})$ in case of $T$. nivea. These findings clearly indicated that extracts has remarkable
\end{abstract}

All the article published by Journal of Experimental Biology and Agricultural Sciences is licensed under a Creative Commons Attribution-NonCommercial 4.0 International License Based on a work at www.jebas.org.

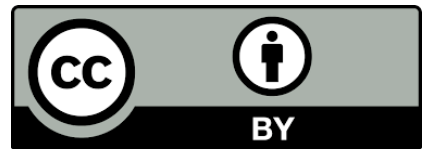


antibacterial activity against MRSA. This investigation supports the traditional use of truffles for the treatment of eye infection and proved its effectiveness against MRSA which could be considered as promising antibiotic drug in near future.

\section{Introduction}

Now in these days use of antibiotics has frequently increased. The excessive and improper use of antibiotics not only increasing the resistance in microorganisms but also adversely affect the immune system. The severe side effects of the currently used antibiotics and its high production cost pushed researchers to find out new alternative source of antibiotics which should be safe and effective. Ancient literatures suggest the use of desert truffles as an alternative of commercial antibiotics (Wang \& Marcone, 2011; Patel et al., 2017; Schillaci et al., 2017).

Desert truffles are hypogenous fungi that have been used as medicine and food for centuries in Saudi Arabia and many other countries around the world (Lo \& Kam, 2006; Al-Qarawi \& Mridha, 2012; Charoensiddhi et al., 2017). According to the local experts, these truffles grew in very rare environment when limited rain occurred between February to April. When there is more rain falls, the chances to have high yield of truffles increased. After 40-50 days of the first rain fall people start searching truffles in cracks formed on the ground (Sawaya et al., 2006; Hamza et al., 2016a). The interactions between growing truffles are very vital in ecological systems as the mycorrhizal species have the potential to avoid erosion and desertification by sand stabilization. Mycorrhizal fungi also modify water relations in host plants (Benzeggouta, 2014). Among various reported species of desert truffles two types "T. nivea and T. claveryi" are very common in Saudi Arabian climatic conditions. Among these two, T. nivea is locally known as Zubaidi and had a meat like texture with white colored skin while $T$. claveryi is similar to the potatoes in texture and have brown colored skin and locally known as Khalasi. Both of these belong to the family of Terfeziaceae and were used in the current research.

The importance and chemical composition of desert truffles has been well documented particulaly in their proteins and amino acids contents which is higher than many other edible mushrooms. It proved highly nutritious and digestible for humans and comprises approximately $85 \%$ amino acids, $27 \%$ protein, $60 \%$ carbohydrates (glycerol, glucose, fructose, mannitol, inositol and trehalose in varying quantities), 2 to $5 \%$ ascorbic acid, 3 ot $7.5 \%$ fat (unsaturated and saturated fatty acids), and7 to $13 \%$ crude fiber (Dundar et al., 2012; Garcia-Vaquero et al., 2017).

The extracts of desert truffles have anti-bacterial properties against a wide range of bacteria and widely used in the treatment of trachoma (Alhussaini et al., 2016). It is also successfully used against Gram-positive human pathogenic reference strain Staphylococcus aureus ATCC 29213 and Gram-negative strain Pseudomonas aeruginosa ATCC 15442 (Janakat et al.,2005; AlQarawi \& Mridha, 2012; Pádua et al., 2015; Neggaz et al., 2015; Schillaci et al., 2017). Gouzi et al. (2011) tried aqueous extract of the truffles against Staphylococcus aureus and Pseudomona aeruginosa and exhibits remarkable zone of inhibition. Desert truffles comprise a vast unexploited therapeutic compounds such as phenolics, tocopherols, ascorbic acid and carotenoids which have remarkable medicianl properties along with antioxidant potential (Al-Laith, 2010; Balboa et al., 2013; Özyürek et al., 2014; Sanjeewa et al., 2016; Gargano et al., 2017; Pinteus et al., 2017).

Desert truffles have nutritional value due to their proteins, carbohydrates, fats, fibers, and low energy. They also have immune-modulating, hepatoprotective, antidepressant, antibacterial, antifungal, antiviral, antioxidant, and antiradical properties due to their content of phenol, carotenoid, anthocyanin, ascorbic acid, flavonoid, tannin, glycoside, ergosterol, etc. Hence, the introduction of desert truffles in the pharmacological field is important, especially in the treating of eye infections and cancer (Janakat \& Nassar, 2010; Hamza et al., 2016b; Khadri et al., 2017; Owaid, 2018). Moreover, studies on higher mushrooms showed antibacterial activity against Escherichia coli, Pseudomonas aeruginosa and Staphylococcus aureus (Imtiaj \& Lee, 2007).

Staphylococcus is common nasal bacteria can cause serious infectious diseases in skin and other mucous membranes and at severe infections it might cause lung infection and pneumonia. Methicillin resistant $S$. aureus (MRSA) usually developed and showed resistance against beta-lactam antibiotics. One of the most effective methods for preventing the spread of MRSA requires detection of colonized HCWs and measuring the associated risk factors of colonization (Kaur \& Chate, 2015). MRSA is strain of Staphylococcus aureus that developed by multidrug resistance to $\beta$-lactam antibiotics which include Penicillin, Methicillin, dicloxacillin, naficillin, Oxacillin (Appelbaum, 2007; Kaur \& Chate, 2015). The first report of methicillin resistant S. aureus (MRSA) was from London in 1961 (Cookson, 2011). This bacterium is capable in causing sever serious infections in humans forming skin infections such as boils and abscesses (Hiramatsu et al., 2014). They can also burrowed deep into the body, causing potentially life-threatening infections in bones, joints, surgical wounds, the bloodstream, heart valves and lungs (MayoClinic, 
2015). The virulence of this $S$. aureus comes from its ability to adapt to a variety of changing environmental conditions and to modulate its pathogenicity. It can establish asymptomatic carriage, which permits widespread dissemination among human hosts. It also has a remarkable proclivity to acquire resistance to multiple antimicrobial agents, which causes therapeutic challenges for physicians (Moellering, 2010). It has been suggested that the mecA gene is responsible for $S$. aureus resistance to methicillin. MecA encodes an altered penicillinbinding protein (PBP2a) with a low affinity for $\beta$-lactam antibiotics (Grundmann et al., 2006). MRSA was previously considered as a nosocomial pathogen, but in the past two decades, reports suggest an increasing trend for community-associated MRSA (CAMRSA). These clones may replace current health care-associated MRSA (HA-MRSA) clones in the future. This hypothesis is supported not only by mathematical models but also by reports that have shown invasion of CA-MRSA clones to hospitals (Moellering, 2010). First described in Minnesota, CAMRSA has now attracted global attention (DeLeo et al., 2010). MRSA related to livestock infections has also been reported (Bortolami et al., 2017). However, this type of MRSA seems to be limited to some countries, especially the ones where pig farms are common (Angen et al., 2017). Some European countries have maintained low rates of MRSA (Köck et al., 2010; Stefani et al., 2012). However, an increase in the worldwide prevalence of MRSA highlights the urgent need of finding alternative solutions to this emerging problem (Graveland et al., 2011; Stefani et al., 2012). Keeping in view all these facts and findings, the present study aimed to determine the antibacterial activity of aqueous extract obtained from two varieties of desert truffles against MRSA bacteria.

\section{Materials and Methods}

\subsection{Preparation of the Desert Truffles Extracts}

\subsubsection{Desert Truffles Collection}

Two types of desert truffles T. claveryi (Khallasi) and T. nivea (Zubaidi) $(1 \mathrm{Kg}$ each) were collected from guard fence, Al-Ahasa Street, Riyadh (East), Saudi Arabia.

\subsubsection{Truffle Crude Extracts}

The crude truffles extract was prepared according to method described by Janaket et al. (2004). Fifty grams of truffles were cut into small pieces and soaked in distilled water (1:3) for $24 \mathrm{~h}$. The mixture was homogenized for $1 \mathrm{~min}$ at full speed and homogenate was filtered through double layer of sterile cheese cloth (sterile gauze was used instead of it) and centrifuged at $3000 \times \mathrm{g}$ for 10 min at $4^{0} \mathrm{C}$ in order to remove its soluble material. The supernatant constitute the crude aqueous extract was recovered and filtered under sterile condition through a $0.22 \mu \mathrm{m}$ filter. The obtained sterile filtrate was than kept at $-15^{\circ} \mathrm{C}$ until use.

\subsection{Subjects}

A retrospective observational chart review was conducted of surveillance MRSA nasal-swab screening and corresponding culture results for clinical isolates. MRSA screening nasal specimens were collected using sterile cotton swabs (ACI Saudi Plast labs, Jeddah,Saudia Arabia) as per laboratory standard operating procedures. Nasal samples were collected from Fifty Health Care Workers (HCWs) and Community Volunteers (CV) by ENT specialist from King Abdulaziz University Hospital (KAUH), Jeddah, Saudi Arabia. Eligible subjects for that trial also included those patients admitted to the Hospital with a history of MRSA infection or colonization $\geq 90$ days from the day of admission. The subjects were approached and attempts were made to screen them on days 1, 2, and 3 of hospitalization. The swabs were simultaneously inoculated and assessed on Manntiol Salt agar for the presence of S.aureus colonies and further subculture on Muller-Hinton agar for the isolation and identification of MRSA.

A total of 50 MRSA isolates from nasal specimens were randomly selected for further analysis. These isolates were also tested for routine antibiotics by Kirby-Bauer disk diffusion method on Mueller-Hinton agar as per Clinical and Laboratory Standards Institute (CLSI).

The study was approved by Research Ethics Committee of Faculty of Medicine, King Abdulaziz University, Jeddah, Saudi Arabia. All volunteers hospital staff signed informed consent and the questioners before being included in this study because of the retrospective nature of the study.

\subsection{Antibiotics Susceptibility Testing (AST)}

\subsubsection{Disc Diffusion Test (DD test)}

Antibiotic susceptibility tests of all MRSA isolates were performed using a disk diffusion method on Muller Hinton agar with antibiotic discs of Oxacillin $(1 \mu \mathrm{g})$, Ampicillin $(10 \mu \mathrm{g})$, Ciprofloxacin $(5 \mu \mathrm{g})$ and Azithromycin $(15 \mu \mathrm{g})$, then interpreted according to the Clinical \& Laboratory Standards Institute (CLSI, 2007) guidelines. Each bacterial isolate were initially considered MRSA, if the test results of inhibition zones for Oxacillin was $\leq 10 \mathrm{~mm}$. 


\subsubsection{Agar Well Diffusion Method}

Bacteria (1 ml) were spread on the surface of Muller Hinton agar evenly and the excess was withdrawn by micro-pipette. Wells of six mm diameter were punched into the agar and filled with 100 $\mu 1$ of the aqueous extracts of truffles $T$. claveryi (Khallasi) and $T$. nivea (Zubaidi). Plates were kept first at $4^{0} \mathrm{C}$ for at least $2 \mathrm{hrs}$ to allow the diffusion of any antibacterial metabolites and then there were incubated for $24 \mathrm{hrs}$ at $37^{\circ} \mathrm{C}$. The antibacterial effects of aqueous extracts of the two varieties of truffles were compared with those of Oxacillin, Ampicillin, Ciprofloxacin and Azithromycin antibiotics which usually employed against pathogenic strains. All experiments were carried out in Triplicate. The antimicrobial activity was determined by observing the zone of inhibition (ZOI).

\subsection{DNA Eextraction}

DNA was extracted using Gene JET Genomic DNA Purification Kit \#K0722 (Thermo Scientific, USA) according to the manufacturer's protocol.

\subsection{Agarose Gel Preparation}

Gels with a concentration of $2 \%(w / v)$ agarose were used for gel electrophoresis. Each gel consisted $2 \mathrm{~g}$ agarose and 100m 1X TAE buffer. The solution was melted in a microwave (about 2-3 min) until the agarose was completely dissolved and the solution appeared clear. After melting the solution was cooled down to approximately $65^{\circ} \mathrm{C}$ and $2 \mu 1$ of ethidium bromide solution were added, mixed well and poured into a prepared gel casting tray for cooling, until the gel looked milky and became solid.

\subsection{Polymerase chain reaction (PCR)}

DNA $(8 \mu \mathrm{l})$ was amplified in $25 \mu \mathrm{l}$ reaction by using the master mix from Promega (GoTaq ${ }^{\circledR}$ Green Master Mix (2X), M7122, USA). The primers were designed based on the highly conserved of mecA gene from Eurofins Genomics (Germany).

The mecA gene was amplified by PCR using previously reported primers (Table 1). DNA amplification was carried out in thermal cycler (multigene ${ }^{\mathrm{TM}}$ optimax thermal cycler, model no. 66TC9610) supplied from Lab net International, USA. The reaction cycles for each gene included, initial denaturation at $94^{\circ} \mathrm{C}$ for 4 min followed by 40 cycles of amplification (denaturation at $94^{\circ} \mathrm{C}$ for 30 secs, annealing at $55^{\circ} \mathrm{C}$ for 30 secs, and extension at $72^{\circ} \mathrm{C}$

Table 1 Primer Sequence of mecA gene

\begin{tabular}{|cc|}
\hline Gene name & Primer sequence \\
\hline \multirow{2}{*}{ mecA } & FP : 5'ATAGAGATGCTGGTACAGG3' \\
\cline { 2 - 2 } & RP : 5'GCTTCCGATTGTTCGATGC3' \\
\hline
\end{tabular}

for $1 \mathrm{~min}$ ) and a final extension at $72^{\circ} \mathrm{C}$ for $5 \mathrm{~min}$. PCR products were run through a $2 \%$ agarose gel (in $1 \mathrm{X}$ TAE buffer) containing Ethidium bromide $(2 \mu 1 / 100 \mathrm{ml}$ agarose solution) at $80 \mathrm{~V}$ for 45 min. In parallel, a $1 \mathrm{~Kb}$ DNA ladder (CSL-MDNA-1Kb, Cleaver Scientific Ltd, UK) ranging from $250-10 \mathrm{~Kb}$ was applied to determine the size of the DNA. DNA fragments were visualized through UV light.

\subsection{Statistical Analysis}

The statistics were performed by using Windows Microsoft Excel 2013 software, using t-test to detect the significance at $\mathrm{p}$ - value $(\mathrm{p}<0.05)$.

\section{Results and Discussion}

In this study, the antibacterial properties of both truffles $T$. claveryi and $T$. nivea aqueous extracts on the growth of MRSA were evaluated and promising results were obtained. In agar well diffusion method, T. claveryi was reported more effective against MRSA $(27 \pm 7.75 \mathrm{~mm}$ zone of inhibition) as compared to $T$. claveryi (22.5 $\pm 11.26 \mathrm{~mm}$ zone of inhibition) (Table 2; Figure 1). These findings are in agreement with the study of Gouzi et al. (2011) and Casarica et al. (2016). Similarly, Neggaz \& Fortas (2013) suggested that ethyl acetate extract of Tirmania pinoyi

Table 2 Comparison ZOI of antimicrobial activity between T.claveryi and T.nivea aqueous extracts and antibiotics discs.

\begin{tabular}{|c|ccccc|c|}
\hline $\begin{array}{c}\text { Test } \\
\text { bacteria }\end{array}$ & $\begin{array}{c}\text { T.claveryi } \\
100 \mu \mathrm{l}\end{array}$ & $\begin{array}{c}\text { T. nivea } \\
100 \mu \mathrm{l}\end{array}$ & $\begin{array}{c}\text { OX } \\
1 \mu \mathrm{g}\end{array}$ & $\begin{array}{c}\text { AMP } \\
10 \mu \mathrm{g}\end{array}$ & $\begin{array}{c}\text { AZM } \\
15 \mu \mathrm{g}\end{array}$ & $\begin{array}{c}\text { CIP } \\
5 \mu \mathrm{g}\end{array}$ \\
\hline MRSA & $27 \pm 7.75$ & $22.5 \pm 11.26$ & $9 \pm 6.65$ & $11 \pm 6.35$ & $21 \pm 9.07$ & $23 \pm 2.5$ \\
\hline
\end{tabular}
(OX), Ampicillin (AMP), Azithromycin (AZM), C iprofloxacin (CIP)

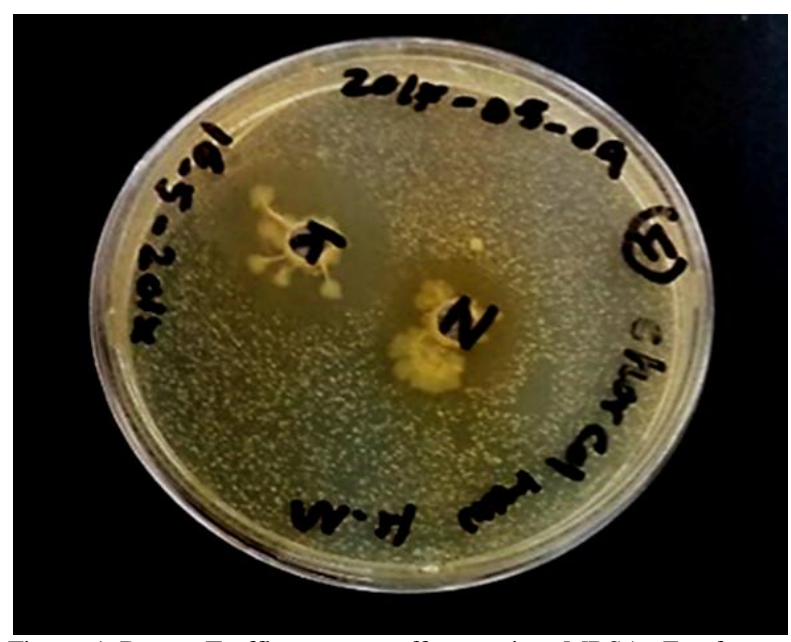

Figure 1 Desert Truffle extracts effect against MRSA, Z refers to Zubidi (Terfiza nivea) $\mathrm{K}$ refers to ikhalasi (Terfiza calvayn).

Journal of Experimental Biology and Agricultural Sciences http://www.jebas.org 
have significant inhibitory activity against Gram negative and Gram positive bacteria and have antifungal activity against Candida albicans. Results of these studies conclude that desert truffles had antibacterial and antifungal activity against many bacteria and fungi spices that support the traditional use of truffles. The results obtained from antibiotic susceptibility/resistant test showed that MRSA exhibited high resistant against Ampicillin and Oxacillin and sensitive for Azithromycin and Ciprofloxacin, as compared to the desert truffles extract values. It was clearly reported that the aqueous extracts of both truffles possessed higher antibacterial activity against MRSA than the $1 \mu \mathrm{g}$ Oxacillin, $10 \mu \mathrm{g}$ Ampicillin, $15 \mu \mathrm{g}$ Azithromycin and $5 \mu \mathrm{cg}$ Ciprofloxacin (Table 2). These results are in agreement with the findings of Gouzi et al. (2011).

At confidence level 95\%, the $\mathrm{p}$ value $=0.2765$ considered non significant association between the truffles extracts and MRSA sensitive antibiotics (Ciprofloxacin and Azithromycin) but there were significance association between the truffles extracts and MRSA resistant antibiotics (Oxacillin and Ampicillin) with $\mathrm{p}$ value $=0.0353($ Table $3 \& 4)$.

The in vitro antibacterial activity of 3 edible desert truffle mushrooms species aqueous extracts (Tirmania pinoyi, Terfezia claveryi and Picoa juniper) against Gram-positive human pathogenic reference strain Staphylococcus aureus ATCC 29213 and the Gram-negative strain Pseudomonas aeruginosa ATCC 15442 are recently reported by Schillaci et al. (2017). Aqueous extract of the truffle Terfezia claveryi contains a potent antimicrobial agent that is protein in nature and may be used in the treatment of eye infections caused by $P$. aeruginosa. Relative antimicrobial activities of these truffles fractions were found to be superior to most of reference antibiotics used (Janakat et al., 2005).

Disc diffusion test (DD test) was used to detect antibiotic sensitivity of MRSA isolates. Results of study revealed that out of $50 \mathrm{~S}$. aureus isolates, 23 (46\%) isolates were found resistant to Ampicillin and Oxacillin and sensitive for Azithromycin and Ciprofloxacin (Table 3 \& 4). Staphylococcal resistance to Oxacillin occurs when the organism including an altered Penicillin-Binding Protein (PBP2A) that is coded by the mecA gene (Fishovitz et al., 2014). Oxacillin showed stability under storage conditions. Oxacillin resistant isolates were initially interpreted as MRSA based on DD test which were not proved after further investigations. It was also observed that phenotypic methods to detect methicillin resistance in S. aureus (MRSA) are inadequate and need more developments. These results also supported by Alipour et al. (2014) who described that DD assay from a single specimen is not optimal for the rapid detection of MRSA.
Table 3 MRSA isolates occurrence percentage to the antibiotics via susceptible / resistant test (DD test).

\begin{tabular}{|c|c|c|c|c|c|c|c|c|c|}
\hline \multirow[b]{2}{*}{ Antibiotics } & \multirow{2}{*}{ SM } & \multirow[t]{2}{*}{$\mathrm{SF}$} & \multirow{2}{*}{ VM } & \multirow{2}{*}{$\mathrm{VF}$} & \multirow{2}{*}{$\begin{array}{c}\text { Susceptible } \\
\text { (Sensitive) }\end{array}$} & \multicolumn{2}{|c|}{$\begin{array}{c}\text { S.aureus } \\
\text { (Resistant) }\end{array}$} & \multicolumn{2}{|c|}{$\begin{array}{c}\text { MRSA } \\
\text { (Resistant) }\end{array}$} \\
\hline & & & & & & No. & $\%$ & No. & $\%$ \\
\hline Oxacillin & 1 & 8 & 6 & 8 & 27 & 23 & $46 \%$ & - & - \\
\hline Ampicillin & 4 & 13 & 11 & 20 & 2 & 48 & $96 \%$ & 22 & $(45.83 \%)$ \\
\hline Azithromycin & 2 & 3 & 2 & 6 & 37 & 13 & $26 \%$ & 12 & $(92.31 \%)$ \\
\hline Ciprofloxacin & 0 & 4 & 1 & 0 & 45 & 5 & $10 \%$ & 3 & $(60 \%)$ \\
\hline
\end{tabular}

Here SM. Staff male, SF. Staff female, VM.Volunteer male, VF. Volunteer female

Table 4 Relationship of biophysical parameters and the prevalence of MRSA

\begin{tabular}{|c|c|c|c|c|c|}
\hline \multicolumn{2}{|c|}{ Parameter } & Df & t-value & SD & P-value \\
\hline \multirow{2}{*}{$\begin{array}{l}\text { Desert } \\
\text { truffles } \\
\text { extract }\end{array}$} & MRSA S.AB & 1 & \multirow{2}{*}{2.3} & 1.41 & $0.2765^{* *}$ \\
\hline & MRSA R.AB & 1 & & 6.36 & 0.0353 \\
\hline & Age & 3 & 2.45 & 19.37 & 0.0018 \\
\hline & Gender & 1 & 4.3 & 14.14 & $0.2597 * *$ \\
\hline & Group & 3 & 2.45 & 6.56 & $0.0670 * *$ \\
\hline
\end{tabular}

* No significant difference, S; Sensitive, R; Resistant AB; Antibiotics

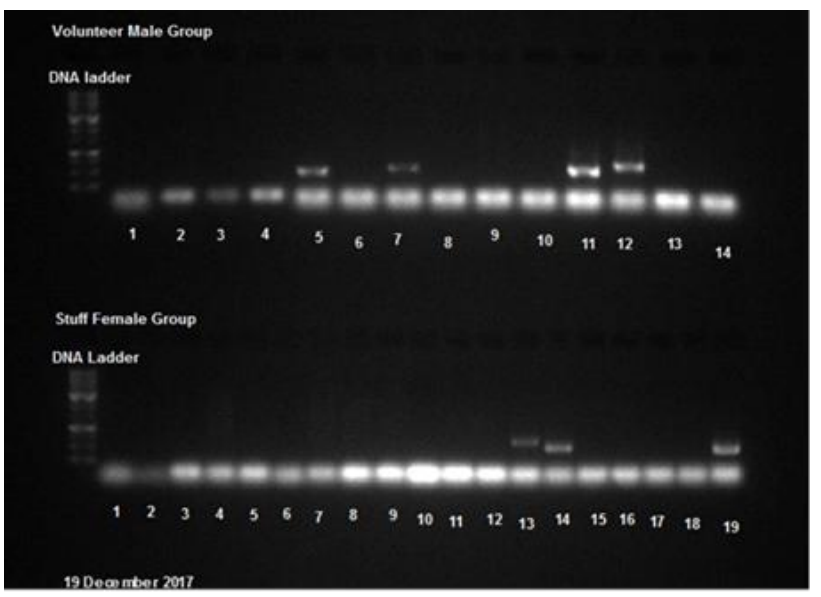

Figure 2: $2 \%$ agarose gel electrophoresis of $m e c \mathrm{~A}$ gene $\mathrm{PCR}$ products where lane 1:1 Kb DNA ladder and lane 1-14(VM), 1-19(SF): PCR product.

PCR assay results showed that among randomly selected 50 MRSA isolates, 17 MRSA isolates showed the presence of two types of plasmid bands at 500 bp and 750 bp after gel electrophoresis. The 500bp band was the most common (76.47\%) while 750 bp band observed only in $23.52 \%$ gel electrophoresis samples which indicating the presence of mecA gene. It also showed that 17 (34\%) MRSA strains isolated from nasal carriage found positive as MRSA in PCR analysis (Figure 2-4). Alipour et al. (2014) observed 37\% of positive isolates by PCR assays and also recorded the presence of 


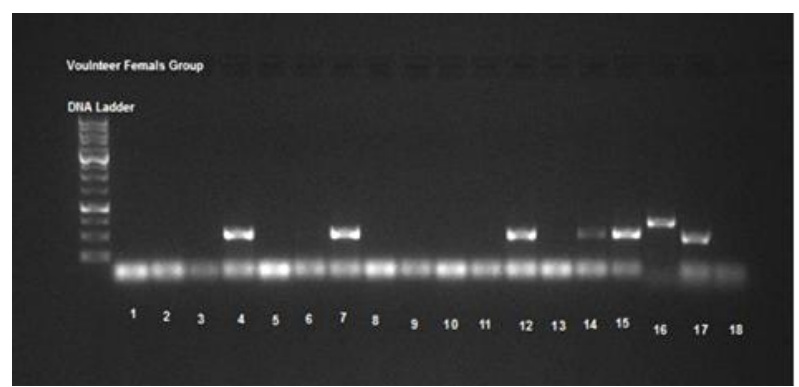

Figure 3: $2 \%$ gel electrophoresis of mecA gene PCR products where lane 1:1 Kb DNA ladder and lane 1-18(VF): PCR product

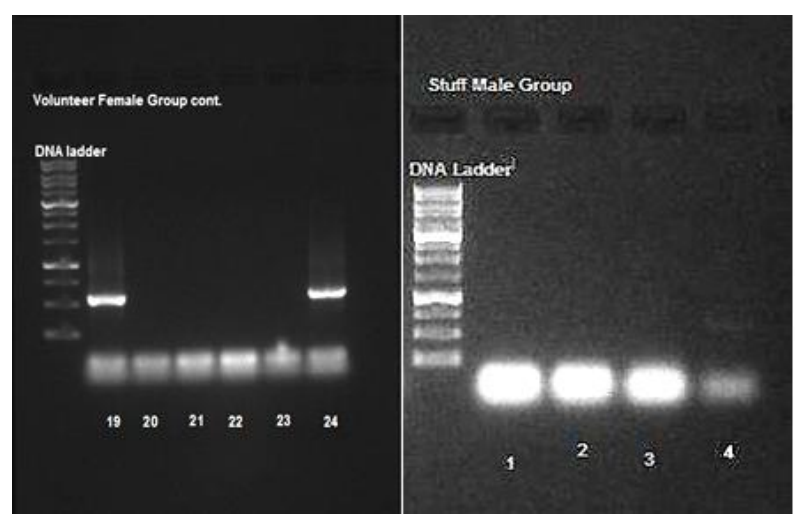

Figure 4: $2 \%$ gel electrophoresis of mecA gene PCR products where lane 1:1 Kb DNA ladder, a) lane 19-24 (VF) and b) lane 1-4(SM): PCR product.

mecA. Further results of study showing that $8 \%$ hospital staff comprised of $1(2 \%)$ male (SM) and $3(6 \%)$ female (SF) have MRSA occurrence. In volunteer female (VF), 9 out of 19 samples (18\%) were positive; while in volunteer male (VM) 4 out of 11 were found positive (Table 4). These finding are supports by the study of Jaffe et al. (2000). MRSA significance was tested for age, gender and groups. It showed that there was significant difference between MRSA and age ( $\mathrm{p}$ value $=0.0018$ ). Among these 20-29 age group respondents had 10 positive samples while 30-39 age group had 5 positive samples and 40-49 have 2 positive samples. The negative MRSA samples were observed at age range 50-59 (Table 3). The highest rate of MRSA was reported for the age group of 20-29 years, among the youngest participants. Positive throat carriage MRSA, who even not exposed to health care system, was more common in 30 years and younger participants (Mertz et al., 2009). The gender and MRSA positive results showed no significant association with ( $\mathrm{p}$ value $=0.2597$ ) even though $24 \%$ of female and $10 \%$ of Male had MRSA carriage. These findings were in contrary with the findings of Kupfer et al. (2010) who confirmed that male gender were at higher risk of MRSA carriage. Further, no significant association was reported between Hospital Staff Male (SM), Female (SF) and community Volunteer Male $(\mathrm{VM})$ and Female $(\mathrm{VF})$ groups (p value $=0.0670$ ).
This result was also in contrast with the findings of Cesur \& Çokça, (2004) study who reported that hospital staff are more likely to be MRSA carrier ( $\mathrm{p}$ value $=0.013$ ) than the outpatient but it was in agreement with the study of Alsulami et al. (2017) who reported non significant difference between groups of units.

Our findings showed the Community-Associated MRSA had highest prevalence rate than the hospital-associated MRSA. Previous studies also reported that increasing in the occurrence of community-acquired MRSA lineages plus emergence of pandemic and rare MRSA strains is occurring now in these days (Senok et al., 2016). Due to this reason, the Methicillin-Resistant $S$. aureus USA300 strain has became the dominant strain in hospitals as well as in the community because of its unique characteristics. Type IV SCCmec cassette in USA300 is smaller than types I-III in hospital-acquired MRSA (HA-MRSA). Community acquired CA-MRSA including USA300 carry fewer antibiotic resistance genes than HA-MRSA. Doubling time of USA300 is shorter by $\sim 1.25$-fold. Linkage of arginine catabolic element with SCCmec IV in USA 300 confers increased fitness and pathogenicity of this strain. These characteristics made this strain as a type causes most community-associated MRSA infections and is an increasingly common cause of health care-associated MRSA infections (Moellering, 2010). In this study, after combining the observations about MRSA prevalence and its solution from AST/DD test and PCR assays have accurately revealed that MRSA rate had raised among community associated MRSA (CAMRSA). Analyzing genotyping studies enabled us to track the emergence of a new, successful MRSA type in space and time across the countries. The prevalence of desert truffles species with multiple antibacterial traits emphasizes its potential for use and development of effective antimicrobial drug that could be used to improve the human health against MRSA. Further studies must be carried out in large and identical group numbers to have more precise outcomes.

\section{Conclusion}

This study has shown that the aqueous extract of $T$. nivea and $T$. claveryi desert truffles exhibited antibacterial activity against MRSA. The antibacterial potential of $T$. claveryi was stronger and effective than the $T$. nivea extract. Molecular detection by PCR assays had identified the frequent prevalence of MRSA among community associated MRSA (CA-MRSA). This investigation supports the traditional use of truffles for the treatment of eye infection and proved its effectiveness against MRSA which could be considered as promising antibiotic drug of future use.

\section{Acknowledgement}

Authors acknowledge the contribution of Dr. Eman Faisal, Head of Microbiology Lab, King Fahad Hospital Laboratories, Jeddah, 
Saudi Arabia as well as her coworkers as volunteers for completion of this study.

\section{Conflict of Interest}

Authors would hereby like to declare that there is no conflict of interests that could possibly arise.

\section{References}

Al Laith AAA (2010) Antioxidant components and antioxidant/antiradical activities of desert truffle (Tirmania nivea) from various Middle Eastern origins. Journal of Food Composition and Analysis 23: 15-22.

Al Qarawi A, Mridha AU (2012) Status and need of research on desert truffles in Saudi Arabia. Journal of Pure and Applied Microbiology 6:1051-1061.

Alhussaini MS, Saadabi AM, Hashim K, Abdullah A, AlGhanayem AA (2016) Efficacy of the desert truffle Terfezia claveryi to cure trachoma disease with special emphasis on its antibacterial bioactivity. Trends in Medical Research 11 : 28-34.

Alipour F, Ahmadi M, Javadi S (2014) Evaluation of different methods to detect methicillin resistance in Staphylococcus aureus (MRSA). Journal of Infection and Public Health 7: 186-191.

Alsulami SO, Al Doghaither HA, Iyer AP (2017) Detection of methicillin resistant Staphylococcus aureus isolated from nasal carriage of health care workers by polymrase chain reaction. Journal of Experimental Biology and Agricultural Sciences 5:288-293.

Angen O, Feld L, Larsen J, Rostgaard K, Skov R, Madsen AM, Larsen AR (2017) Transmission of methicillin-resistant Staphylococcus aureus to human volunteers visiting a swine farm. Applied and Environmental Microbiology 83:e01489-17.

Appelbaum PC (2007) Microbiology of Antibiotic Resistance in Staphylococcus aureus. Clinical Infectious Diseases 45:S165-70.

Balboa EM, Conde E, Moure A, Falqué E, Domínguez H (2013) In vitro antioxidant properties of crude extracts and compounds from brown algae. Food Chemistry 138: 1764-1785.

Benzeggouta N (2014) Mini review: why desert truffles "Terfès" exist in sahara? Journal of Materials Science and Engineering 4:380-383

Bortolami A, Verin R, Chantrey J, Corrò M, Ashpole I, Lopez J, Timofte D (2017) Characterization of livestock-associated methicillin-resistant Staphylococcus aureus CC398 and mecCpositive $\mathrm{CC} 130$ from zoo animals in the United Kingdom. Microbial Drug Resistance 23 : 908-914.
Casarica A, Moscovici M, Daas M, Nicu I, Panteli M, Rasit I (2016) A Purified extarct from brown truffles of the species Terfeziclaveryi chatin and its antimicrobial activity. Farmacia 64:298-301.

Cesur S, Çokcs F (2004) Nasal carriage of methicillin resistant Staphylococcus aureus among hospital staff and outpatients. Infection Control \& Hospital Epidemiology 25: 169-171.

Charoensiddhi S, Conlon MA, Franco CMM, Zhang W (2017) The development of seaweed-derived bioactive compounds for use as prebiotics and nutraceuticals using enzyme technologies. Phytochemistry Letters 14: 91-98.

Clinical and Laboratory Standards Institute (2007) M100-S17. Performance standards for antimicrobial susceptibility testing; $16^{\text {th }}$ informational supplement. Clinical and Laboratory Standards Institute, Wayne, PA.

Cookson B (2011) Five decades of MRSA: controversy and uncertainty continues. The Lancet 378: 1291-1292.

Deleo FR, Otto M, Kreiswirth BN, Chambers HF (2010) Community associated meticillin resistant Staphylococcus aureus. The Lancet 375: 1557-1568.

Dundar A, Faruk YO, Acay H, Okumus V, Ozdemir S, Yildiz A (2012) Antioxidant properties, chemical composition and nutritional value of Terfezia boudieri (Chatin) from Turkey. Food Science and Technology International 18:317-28.

Fishovitz J, Juan A. Hermoso, Chang M, Mobashery S (2014) Penicillin-binding protein $2 \mathrm{a}$ of methicillin-resistant Staphylococcus aureus. IUBMB Life 66: 572-577.

Garcia-Vaquero M, Rajauria G, O'Doherty JV, Sweeney T (2017) Polysaccharides from macroalgae: Recent advances, innovative technologies and challenges in extraction and purification. Food Research International 99:1011-1020.

Gargano ML, Bella P, Panno S, Arizza V, Inguglia L, Catara V , Venturella G, Davino S (2017) Antimicrobial activity of the extracts of Terfezia claveryi and Tirmania pinoyi against Grampositive and Gram-negative bacteria causal agent of diseases in tomato. Chemical Engineering Transactions 58:73-78.

Gouzi H, Belyagoubi L, Abdelali KN, Khelifi A (2011) In vitro antibacterial activities of aqueous extracts from Algerian desert truffles (Terfezia and Tirmania, Ascomycetes) against Pseudomonas aeruginosa and Staphylococcus aureus. Journal of International Medicinal Mushrooms 13: 553-558.

Graveland H, Duim B, Van Duijkeren E, Heederik D, Wagenaar JA (2011) Livestock associated methicillin resistant 
Staphylococcus aureus in animals and humans. International Journal of Medical Microbiology 301:630-634.

Grundmann H, Aires de Sousa M, Boyce J, Tiemersma E (2006) Emergence and resurgence of meticillin resistant Staphylococcus aureus as a public-health threat. The Lancet 368: 874-885.

Hamza A, Jdir H, Zouari N (2016a) Nutritional, antioxidant and antibacterial properties of Tirmania nivea, a wild edible desert truffle from Tunisia arid zone. Medicinal and Aromatic Plants 5(4):1-4.

Hamza A, Zouari N, Zouari S, Jdir H, Zaidi S, Gtari M, Neffati M (2016b) Nutraceutical potential, antioxidant and antibacterial activities of Terfezia boudieri Chatin, a wild edible desert truffle from Tunisia arid zone. Arabian Journal of Chemistry 9:383-389.

Hiramatsu K, Katayama Y, Matsuo M, Sasaki T, Morimoto Y, Sekiguchi A, Baba T (2014) Multi-drug-resistant Staphylococcus aureus and future chemotherapy. Journal of Infection and Chemotherapy $20: 593-601$.

Imtiaj A, Lee TS (2007) Screening of antibacterial and antifungal activities from Korean wild mushrooms. World Journal of Agricultural Sciences 3: 316-321.

Jaffe RI, Lane JD, Albury SV, Niemeyer DM (2000) Rapid extraction from and direct identification in clinical samples of methicillin resistant Staphylococci using the PCR. Journal of Clinical Microbiology 38:3407-3412.

Janakat S, AlFakhiri S, Sallal AK (2004) A promising peptide antibiotic from Terfezia claveryi aqueous extract against Staphylococcus aureus in vitro. Phytotherapy Research 18: 810-813.

Janakat S, Nassar M (2010) Hepatoprotective activity of desert truffle (Terfezia claveryi) in comparison with the effect of Nigella sativa in the rat. Pakistan Journal of Nutrition 9:52-56.

Janakat SM, Al-Fakhiri SM, Sallal AK (2005) Evaluation of antibacterial activity of aqueous and methanolic extracts of the truffle Terfezia claveryi against Pseudomonas aeruginosa. Saudi Medical Journal 26(6):952-5.

Kaur DC, Chate SS (2015) Study of antibiotic resistance pattern in methicillin resistant Staphylococcus aureus with special reference to newer antibiotic. Journal of Global Infectious Diseases 7: 78-84.

Khadri H, Aldebasi YH, Riazunnisa K (2017) Truffle mediated (Terfezia claveryi) synthesis of silver nanoparticles and its potential cytotoxicity in human breast cancer cells (MCF-7). African Journal of Biotechnology $16: 1278-1284$.
Köck R, Becker K, Cookson B, Vangemert-pijnen J, Harbarth S, Kluytmans J, Mielke M, Peters G, Skov R, Struelens M (2010) Methicillin resistant Staphylococcus aureus (MRSA): burden of disease and control challenges in Europe. Euro Surveillance 15: 19688.

Kupfer M, Jatzwauk L, Monecke S, Möbius J, Weusten A ( 2010) MRSA in a large German University Hospital: Male gender is a significant risk factor for MRSA acquisition. GMS Krankenhaushygiene Interdisziplinär 5: Doc11.

Lo ACT, Kam KM (2006) Review of molecular techniques for sexually transmitted diseases diagnosis. In: Tang YW, Stratton CW (Eds.), Advanced techniques in diagnostic microbiology, Springer, United States of America (USA) 22:353-386.

Mayoclinic (2015) MRSA infection. Available on https://www.mayoclinic.org/diseases-conditions/mrsa/symptomscauses/syc-20375336 access on 25th April, 2018.

Mertz D, Frei R, Periat N, Zimmerli M, Battegay M, Fluckiger U, Widmera F (2009) Exclusive Staphylococcus aureus throat carriage: at risk populations. Archives of Internal Medicine 169:172-8.

Moellering JRRC (2010) Why has methicillin resistant Staphylococcus aureusbecome such a successful pathogen in adults? Infectious Diseases in Clinical Practice 18: 286-291.

Neggaz S, Fortas Z, Chenni M, El Abed D, Ramli B, Kambouche $\mathrm{N}$ (2015) In vitro evaluation of antioxidant, antibacterial and antifungal activities of Terfezia claveryi Chatin. Pharmacognosie $13: 1-7$.

Neggaz S, Fortas Z (2013) Tests of antibiotic properties of Algerian desert truffle against bacteria and fungi. Journal of Life Sciences 7: 259.

Owaid MN (2018) Bioecology and uses of desert truffles (Pezizales) in the Middle East Walailak. Journal of Science \& Technology $15: 179-188$.

Özyurek M, Bener M, Guclu K, Apak R (2014) Antioxidant/antiradical properties of microwave-assisted extracts of three wild edible mushrooms. Food Chemistry 157: 323-331.

Pádua D ,Rocha E, Gargiulo D, Ramos AA (2015) Bioactive compounds from brown seaweeds: Phloroglucinol, fucoxanthin and fucoidan as promising therapeutic agents against breast cancer. Phytochemistry Letters 14:91-98.

Patel S, Rauf A, Khan H, Khalid S, Mohammad S, Mubarak MS (2017) Potential health benefits of natural products derived from truffles: A review. Trends in Food Science \& Technology 70: 1-8. 
Pinteus S, Silva J, Alves C, Horta A, Fino N, Rodrigues AI, Mendes S, Pedrosa R (2017) Cytoprotective effect of seaweeds with high antioxidant activity from the Peniche coast (Portugal). Food Chemistry 218: 591-599.

Sanjeewa KKA, AKim E, TaeSon K, JinJeon Y (2016) Bioactive properties and potentials cosmeceutical applications of phlorotannins isolated from brown seaweeds: A review. Journal of Photochemistry and Photobiology 162:100-105.

Sawaya WN, Alshalhat A, Alsogair A, Almohammad M (2006) Chemical Composition and nutritive value of truffles of Saudi Arabia. Journal of Food Science 50 : 450-453.

Schillaci D, Cusimano MG, Cascioferro SM, Di Stefano V, Arizza V, Chiaramonte M, Inguglia L, Bawadekji A, Davino S, Gargano ML, Venturella G (2017) Antibacterial activity of desert truffles from Saudi Arabia against Staphylococcus aureus and
Pseudomonas aeruginosa. International Journal of Medicinal Mushrooms 19(2):121-125.

Senok A, Ehricht R, Monecke S, Al Saedan R, Somliy A (2016) Molecular characterization of methicillin resistant Staphylococcus aureus in nosocomial infections in a tertiarycare facility: emergence of new clonal complexes in Saudi Arabia. New Microbes New Infections 14:13-8.

Stefani S, Chung DR, Lindsay JA, Friedrich AW, Kearns AM, Westh H, Mackenzie FM (2012) Methicillin resistant Staphylococcus aureus (MRSA): Global epidemiology and harmonisation of typing methods. International Journal of Antimicrobial Agents 39: 273-282.

Wang S, .Marcone MF (2011) The biochemistry and biological properties of the world's most expensive underground edible mushroom: Truffles. Food Research International 44 : 2567-2581. 